\title{
Pengaruh Harga, Produk dan Lokasi Terhadap Loyalitas Konsumen Melalui Undang-Undang Perlindungan Konsumen Pada CV. Triple Delapan Group
}

\author{
Anto Tulim ${ }^{1}$, Zetria Erma², Monika Ellis Sukma ${ }^{3}$ \\ ${ }^{1}$ Dosen Tetap S-1 Manajemen, Sekolah Tinggi Ilmu Ekonomi ITMI Medan, Jl. Timah \\ Putih Blok G. 15-17 Komplek Asia Mega Mas Medan 20224 Telp. (061) 7356888 \\ ${ }^{2}$ Dosen Tetap S-1 Hukum, Universitas Pembinaan Masyarakat Indonesia Medan, Jl. \\ Teladan No. 15 Medan 20214, Telp. (061) 7872060 \\ ${ }^{3}$ Mahasiswi S-1 Manajemen, Sekolah Tinggi Ilmu Ekonomi ITMI Medan, Jl. Timah \\ Putih Blok G. 15-17 Komplek Asia Mega Mas Medan 20224 Telp. (061) 7356888 \\ antotulim@yahoo.com, zetriaermaupmi2018@gmail.com dan \\ monikaellis98@gmail.com
}

\begin{abstract}
Consumer loyalty are influenced by price, product and location factors. Companies must have competitive prices, have quality products and have a strategic location in other can be increased consumer loyalty. Price is the amount of money that has been agreed upon by prospective buyers and sellers to be exchanged for goods or services in a business transaction. Products are all things that can fulfill and satisfy human needs or desires, both tangible and intangible. Location is one of the initial activities that must be carried out before the company starts operating determining the right location will affect the company's ability to serve consumers. Consumer loyalty is a consumer's commitment to a product or service by making routine purchases more than twice. Prices that can be reached by consumers, products that are in accordance with their benefits and a location located in the city center will increase consumer loyalty. The purpose of this study was to determine or analyze the effect of price, product and location towards consumer loyalty at CV. Triple Delapan Group Medan. This research was conducted at CV. Triple Delapan Group Medan. The type of research used is descriptive quantitative research. The results showed that price, product and location had a positive and significant effect both partially and simultaneously towards consumer loyalty at $C V$. Triple Delapan Group Medan. The adjusted $R$ square value of $90.7 \%$ indicates that the variable ability of price $\left(X_{1}\right)$, product $\left(X_{2}\right)$ and location $\left(X_{3}\right)$ affects consumer loyalty $(Y)$ at $C V$. Triple Delapan Group Medan while the remaining $9.3 \%$ is the influence of other independent variables that are not explained or not examined by researchers in this study such as promotion, service quality or consumer purchase interest variables.
\end{abstract}

Keywords : Price, Product, Location and Consumer Loyalty.

\section{ABSTRAK}

Loyalitas konsumen dipengaruhi oleh faktor harga, produk dan lokasi. Perusahaan harus memiliki harga yang bersaing, mempunyai produk yang berkualitas dan letak lokasi 
yang strategis sehingga dapat meningkatkan loyalitas konsumen. Harga merupakan jumlah uang yang telah disepakati oleh calon pembeli dan penjual untuk ditukar dengan barang atau jasa dalam transaksi bisnis. Produk merupakan semua hal yang bisa memenuhi dan memuaskan kebutuhan ataupun keinginan manusia baik itu yang berwujud maupun yang tidak berwujud. Lokasi merupakan salah satu kegiatan awal yang harus dilakukan sebelum perusahaan mulai beroperasi penentuan lokasi yang tepat akan mempengaruhi kemampuan perusahaan dalam melayani konsumen. Loyalitas konsumen merupakan komitmen konsumen terhadap produk ataupun jasa dengan melakukan pembelian yang rutin lebih dari dua kali. Harga yang dapat dijangkau oleh konsumen, barang yang sesuai dengan manfaatnya dan lokasi yang terletak di pusat kota akan meningkatkan loyalitas konsumen. Tujuan penelitian ini adalah untuk mengetahui atau menganalisis pengaruh harga, produk dan lokasi terhadap loyalitas konsumen pada CV. Triple Delapan Group Medan. Penelitian ini dilakukan pada CV. Triple Delapan Group Medan. Jenis penelitian yang digunakan adalah penelitian deskriptif kuantitatif. Hasil penelitian menunjukkan bahwa harga, produk dan lokasi berpengaruh positif dan signifikan baik secara parsial maupun secara serempak terhadap loyalitas konsumen pada CV. Triple Delapan Group Medan. Nilai adjusted R square sebesar 90,7\% menunjukkan bahwa kemampuan variabel harga $\left(\mathrm{X}_{1}\right)$, produk $\left(\mathrm{X}_{2}\right)$ dan lokasi $\left(\mathrm{X}_{3}\right)$ berpengaruh terhadap loyalitas konsumen (Y) pada CV. Triple Delapan Group Medan sedangkan sisanya 9,3\% merupakan pengaruh variabel bebas lain yang tidak dijelaskan atau tidak diteliti oleh peneliti dalam penelitian ini seperti variabel promosi, kualitas pelayanan atau minat beli konsumen.

\section{Kata Kunci : Harga, Produk, Lokasi dan Loyalitas Konsumen.}

\section{PENDAHULUAN}

CV. Triple Delapan Group Medan adalah salah satu usaha yang menjual produk handphone. CV. Triple Delapan Group Medan menyediakan berbagai macam merek handphone masa kini. CV. Triple Delapan Group Medan berada di Kompleks Millenium ICT Center No. 28 Medan lantai 1. Dalam menjalankan usahanya CV. Triple Delapan Group Medan berusaha meningkatkan loyalitas konsumen untuk meningkatkan jumlah penjualan pada usahanya.

Dalam penelitian ini peneliti menemukan masalah pada CV. Triple Delapan Group khususnya produk pada CV. Triple Delapan Group Medan dikatakan belum lengkap, tidak menyediakan spesifikasi produk yang terbaru, daya tahan battery handphone atau tidak ada spesifikasi yang tinggi dan desain produk yang ditawarkan tidak menarik bagi konsumen. Hal ini menyebabkan masalah yang terjadi pada produk.

Lokasi pada CV. Triple Delapan Group Medan ini tidak begitu strategis. Konsumen masih kesulitan untuk mencari tempatnya dan CV. Triple Delapan Group Medan tidak memilih lokasi yang banyak dilalui oleh banyak calon konsumen ataupun konsumen yang sudah loyal. Hal ini menyebabkan masalah yang terjadi pada lokasi.

Loyalitas konsumen pada CV. Triple Delapan Group Medan menurun yang dipengaruhi oleh faktor harga. Harga yang ditawarkan pada CV. Triple Delapan Group Medan lebih mahal dibandingkan pada CV. Digital Store, harga yang ditawarkan tidak sesuai dengan spesifikasi handphone yang didapatkan oleh konsumen dan harga handphone yang ditawarkan ke konsumen tidak sebanding dengan manfaat yang diperoleh konsumen. Hal ini menyebabkan masalah yang terjadi pada harga.

Dalam menjalankan usahanya CV. Triple Delapan Group Medan berusaha meningkatkan loyalitas konsumen untuk meningkatkan jumlah penjualan usahanya. 
Namun, dalam hal ini belum sepenuhnya dapat terpenuhi dilihat dari loyalitas konsumen yang menurun. Hal ini dapat dilihat dari jumlah konsumen pada CV. Triple Delapan Group Medan yang menurun drastis. Data Berikut adalah jumlah konsumen pada CV. Triple Delapan Group Medan pada tahun 2018 jumlah pembeli sebanyak 452 orang, pada tahun 2019 mengalami penurunan menjadi 396 orang dan pada tahun 2020 kembali menurun menjadi 278 orang. Hal ini menyebabkan masalah yang terjadi pada loyalitas konsumen.

Mengingat begitu pentingnya pengaruh harga, produk dan lokasi dalam membentuk atau meningkatkan loyalitas konsumen melalui Undang-undang perlindungan konsumen pada perusahaan serta untuk mengetahui bagaimana pengaruh harga, produk dan lokasi terhadap loyalitas konsumen pada CV. Triple Delapan Group Medan maka peneliti tertarik untuk mengadakan penelitian dengan judul penelitian "Pengaruh Harga, Produk dan Lokasi terhadap Loyalitas Konsumen Melalui Undang-undang Perlindungan Konsumen pada CV. Triple Delapan Group Medan".

\section{KAJIAN TEORI Harga}

Menurut Kotler dan Armstrong (2018 : 279) menyatakan bahwa "Harga adalah sejumlah nilai yang ditukarkan konsumen untuk sejumlah manfaat dengan memiliki ataupun menggunakan suatu barang dan jasa". Menurut Swastha (2019 : 158) menyatakan bahwa "Harga merupakan sebuah nilai pengganti yang harus dibayarkan seseorang saat mendapatkan produk yang bermanfaat baginya".

Berdasarkan pendapat para ahli di atas dapat disimpulkan bahwa harga merupakan jumlah uang yang telah disepakati oleh calon pembeli dan penjual untuk ditukar dengan barang atau jasa dalam transaksi bisnis.

Menurut Lupiyoadi (2016 : 204) indikator harga ada lima antara lain :

1. Keterjangkauan Harga

2. Variasi Harga

3. Kesesuaian Harga dengan Kualitas Produk

4. Daya Saing Harga

5. Kesesuaian Harga dengan Manfaat

\section{Produk}

Menurut Kotler dan Armstrong (2018 : 283) menyatakan bahwa "Produk adalah segala sesuatu yang ditawarkan kepada pasar untuk mendapat perhatian, dibeli, digunakan dan dapat memuaskan kebutuhan serta keinginan konsumen". Menurut Amirullah (2016 : 208) menyatakan bahwa "Produk merupakan pemahaman subjektif dari produsen atas sesuatu yang bisa ditawarkan sebagai usaha untuk mencapai tujuan organisasi melalui pemenuhan kebutuhan dan keinginan konsumen sesuai dengan kompetensi atau kapasitas organisasi serta daya beli pasar".

Berdasarkan pendapat para ahli di atas dapat disimpulkan bahwa produk adalah semua hal yang bisa memenuhi dan memuaskan kebutuhan ataupun keinginan manusia baik itu yang berwujud maupun yang tidak berwujud.

Menurut Tjiptono (2017 : 262) indikator produk ada lima antara lain :

1. Kinerja (performance)

2. Fitur atau ciri-ciri tambahan (features)

3. Reliabilitas (reliability)

4. Kesesuaian dengan spesifikasi (conformance to specification) 


\section{Daya tahan (durability)}

\section{Lokasi}

Menurut Manullang (2019 : 143) menyatakan bahwa "Lokasi adalah tempat yang berhubungan di mana perusahaan akan didirikan dan dilaksanakan". Menurut Utami (2016 : 289) menyatakan bahwa "Lokasi merupakan struktur fisik sebuah usaha yang merupakan komponen utama yang terlibat dalam membentuk kesan sebuah usaha yang dilakukan perusahaan dalam melakukan penempatan usahanya dan kegiatan dalam menyediakan saluran pelayanan yang dibutuhkan oleh konsumen”.

Berdasarkan pendapat para ahli di atas dapat disimpulkan bahwa lokasi adalah salah satu kegiatan awal yang harus dilakukan sebelum perusahaan mulai beroperasi.

Menurut Tjiptono (2017 : 278) indikator dalam penentuan lokasi ada empat antara lain :

1. Akses lokasi keberadaan atau letak perusahaan terhadap objek penting seperti pusat perbelanjaan dan fasilitas penunjang lainnya cukup dekat sehingga akan memudahkan konsumen dalam mengakses kebutuhannya.

2. Tempat parkir yang luas dan aman. Kemudahan dalam menempatkan atau memarkir kendaraan tanpa harus ada rasa takut dan was-was akan mendapat gangguan serta kejahatan dari orang lain.

3. Lingkungan yang mendukung. Kenyamanan di tempat sekitar untuk dijadikan wadah sosialisasi dan dapat menjadi komunitas pergaulan yang kondusif.

4. Kemudahan akses menuju perusahaan yang letaknya tidak begitu jauh dan kemudahan akses menuju objek penting dapat meningkatkan minat konsumen untuk mendatangi perusahaan tersebut untuk melakukan pembelian karena dengan kemudahan konsumen tidak harus mengeluarkan biaya tambahan serta harus khawatir dengan lingkungan dari perusahaan tersebut.

\section{Loyalitas Konsumen}

Menurut Rangkuti (2018 : 233) menyatakan bahwa "Loyalitas konsumen adalah sikap menyenangi terhadap suatu produk yang dipresentasikan dalam pembelian yang konsisten terhadap produk tersebut sepanjang waktu". Menurut Tjiptono (2017 : 280) menyatakan bahwa "Loyalitas konsumen merupakan situasi di mana konsumen berprilaku positif kepada produk dan diikuti pola pembelian yang konsisten".

Dari beberapa pendapat para ahli di atas dapat disimpulkan bahwa loyalitas konsumen merupakan komitmen konsumen terhadap barang ataupun jasa dengan melakukan pembelian yang rutin lebih dari dua kali. Menurut Griffin (2018 : 272) menjelaskan indikator loyalitas konsumen ada empat antara lain :

1. Melakukan pembelian ulang secara teratur.

2. Merekomendasikan produk.

3. Kemauan konsumen untuk tetap memakai produk perusahaan.

4. Menunjukkan bahwa kekebalan produk dari daya tarikan produk sejenis dari perusahaan pesaing.

\section{METODE PENELITIAN}

\section{Objek Penelitian}

Subjek penelitian peneliti adalah CV. Triple Delapan Group Medan. Objek penelitian adalah konsumen pada CV. Triple Delapan Group Medan.

Jenis data penelitian ini adalah data primer dan data sekunder. Data primer adalah data yang berasal langsung dari responden melalui penyebaran kuisioner. Data 
sekunder adalah data yang telah disediakan oleh perusahaan yaitu gambaran umum perusahaan, struktur organisasi atau buku yang berkaitan dengan loyalitas konsumen yang diteliti yaitu harga, produk dan lokasi.

\section{Tempat dan Waktu}

Penelitian dilakukan pada CV. Triple Delapan Group Medan yang beralamat di J1. Kapten Muslim Kompleks Millenium ICT Center No. 28 Medan. Waktu penelitian dilaksanakan dari bulan Juli sampai dengan bulan November tahun 2021.

\section{Populasi dan Sampel}

Populasi adalah wilayah generalisasi yang terdiri atas subjek atau objek yang memiliki kualitas dan karakteristik tertentu yang ditetapkan oleh peneliti untuk dipelajari serta ditarik simpulannya (Sugiyono, 2016 : 24). Dalam penelitian ini populasinya adalah seluruh konsumen yang berkunjung untuk membeli handphone pada CV. Triple Delapan Group Medan yang berjumlah 241 konsumen.

Sampel adalah sebagian dari jumlah dan karakteristik yang dimiliki oleh populasi tersebut (Sugiyono, 2016 : 30). Dalam melakukan penelitian tidak harus meneliti seluruh anggota populasi yang menjadi objek penelitian karena dalam banyaknya kasus tidak mungkin seorang peneliti dapat meneliti seluruh anggota populasi (Ferdinand, 2017 : 41). Metodologi pengambilan sampel dalam penelitian ini dilakukan dengan cara siapa saja yang kebetulan bertemu dengan peneliti ini dan dianggap cocok menjadi sumber data akan menjadi sampel penelitian yang berjumlah 71 orang.

Teknik pengambilan sampel menggunakan sampel Slovin.

\section{Teknik Pengumpulan Data}

Teknik pengumpulan data adalah alat bantu yang dipilih dan digunakan oleh peneliti dalam kegiatannya mengumpulkan data agar kegiatan tersebut menjadi sistematis serta dipermudah olehnya (Arikunto, 2017 : 63). berikut :

Teknik pengumpulan data yang digunakan peneliti dalam penelitian sebagai

1. Kuisioner

Kuisioner adalah metodologi pengumpulan data dengan mengajukan daftar pernyataan tertulis tentang masalah yang akan dibahas. Dalam hal ini kuisioner akan dibagikan kepada konsumen CV. Triple Delapan Group Medan sebagai responden.

2. Observasi

Observasi adalah teknik pengumpulan data yang dilakukan dengan cara mengamati langsung objek yang akan diteliti. Observasi ini dilakukan untuk memperoleh gambaran nyata mengenai harga, produk dan lokasi terhadap loyalitas konsumen yang dilakukan CV. Triple Delapan Group Medan.

3. Dokumentasi

Dokumentasi adalah teknik yang digunakan dalam pengumpulan data mengenai data yang diteliti.

4. Wawancara

Wawancara adalah sesuatu proses tanya jawab lisan dalam dua orang atau lebih berhadap-hadapan secara fisik yang satu dapat melihat muka yang lain dan mendengarkan dengan telinga sendiri. Suara merupakan alat pengumpulan informasi yang langsung tentang beberapa jenis data sosial yang baik terpendam (latent) 
maupun yang memanifes (Hadi, 2018 : 223). Dalam penelitian ini dilakukan wawancara kepada konsumen pada CV. Triple Delapan Group Medan.

\section{Uji Kualitas Data}

Pada penelitian ini terlebih dahulu akan dilakukan uji coba dengan membagikan kuisioner 30 orang responden pada CV. Digital Store untuk menguji validitas dan reliabilitas item pernyataan kuisioner.

\section{Uji Validitas}

Uji validitas data dilakukan untuk menguji apakah angket yang disebarkan layak untuk dijadikan instrument penelitian atau tidak. Pengujian validitas dilakukan dengan menggunakan SPSS versi 20.00 dengan kriteria jika nilai validitas setiap pernyataan lebih besar dari 0,30 maka butir pernyataan dianggap sudah valid. Sebaliknya, kalau korelasi antara butir dan skor total kurang dari 0,30 maka butir dalam instrumen tersebut dinyatakan tidak valid. Validitas adalah ukuran yang menunjukkan bahwa sejauh mana instrumen pengukur mampu mengukur apa yang akan diukur.

Pengujian validitas dengan kriteria sebagai berikut :

1. Jika $\mathrm{r}_{\text {hitung }}>\mathrm{r}_{\text {tabel }}$ maka $\mathrm{H}_{1}$ diterima.

2. Jika $\mathrm{r}_{\text {hitung }}<\mathrm{r}_{\text {tabel }}$ maka $\mathrm{H}_{0}$ ditolak.

\section{Uji Reliabilitas}

Menurut Wibowo (2018 : 52) reliabilitas adalah istilah yang dipakai untuk menunjukkan bahwa sejauh mana suatu hasil pengukuran relatif konsisten apabila pengukuran diulangi dua kali atau lebih. Pengujian reliabilitas ini dilakukan dengan tujuan untuk menguji kehandalan atau kepercayaan pengungkapan data. Pengukuran yang mampu memberi hasil yang dipercaya (reliabel). Kriteria ukur reliabilitas ini adalah jika :

1. Nilai Cronchbach's Alpha $>0,60$ maka dinyatakan reliabel.

2. Nilai Cronchbach's Alpha $<0,60$ maka dinyatakan tidak reliabel.

Peneliti menggunakan teknik analisis data sebagai berikut :

1. Metodologi Analisis Deskriptif

2. Uji asumsi klasik

Uji asumsi klasik terbagi 3 yaitu :
a. Uji normalitas
b. Uji multikolinearitas
c. Uji heterokedastisitas

3. Analisis Regresi Linear Berganda

4. Uji F

5. Uji-t

6. Koefisien determinasi $\left(\mathrm{R}^{2}\right)$

\section{HASIL PENELITIAN DAN PEMBAHASAN}

Uji Validitas dan Reliabilitas

Uji Validitas Instrumen Variabel Harga $\left(\mathbf{X}_{1}\right)$

Hasil uji validitas variabel desain produk seperti pada Tabel di bawah ini :

Tabel 1. Hasil Uji Validitas Instrumen Variabel Harga ( $\left.X_{1}\right)$

\begin{tabular}{|c|c|c|c|c|}
\hline No. & Pernyataan & $\begin{array}{c}\text { Corrected Item- } \\
\text { Total }\end{array}$ & $\mathbf{r}_{\text {tabel }}$ & Keterangan \\
\hline
\end{tabular}




\begin{tabular}{|c|l|c|c|c|}
\hline & \multicolumn{1}{|c|}{ Correlation } & & \\
\hline 1. & $\begin{array}{l}\text { Harga handphone pada CV. Digital } \\
\text { Store terjangkau oleh semua kalangan. }\end{array}$ & 0,525 & 0,30 & Valid \\
\hline 2. & $\begin{array}{l}\text { Saya membeli handphone CV. Digital } \\
\text { Store karena menyediakan pilihan } \\
\text { handphone dengan berbagai harga. }\end{array}$ & 0,628 & 0,30 & Valid \\
\hline 3. & $\begin{array}{l}\text { Harga handphone pada CV. Digital } \\
\text { Store sesuai dengan kualitas yang } \\
\text { dibutuhan konsumen. }\end{array}$ & 0,685 & 0,30 & Valid \\
\hline 4. & $\begin{array}{l}\text { Harga handphone pada CV. Digital } \\
\text { Store mampu bersaing dan sesuai } \\
\text { dengan kemampuan atau daya beli } \\
\text { masyarakat. }\end{array}$ & & 0,714 & Valid \\
\hline 5. & $\begin{array}{l}\text { Harga handphone pada CV. Digital } \\
\text { Store sesuai dengan manfaat yang } \\
\text { diperoleh konsumen. }\end{array}$ & 0,699 & 0,30 & Valid \\
\hline
\end{tabular}

\section{Sumber : Hasil Penelitian, 2021 (Data Diolah)}

Berdasarkan Tabel 1. diperoleh bahwa hasil pengujian instrumen dari variabel harga memiliki nilai yang lebih besar dari 0,30. Dengan demikian, dapat disimpulkan bahwa seluruh instrumen pernyataan dari variabel harga yang digunakan adalah valid dan dapat digunakan dalam penelitian ini. Simpulan ini diperkuat dengan signifikan (2-tailed) seluruh instrumen yang lebih kecil dari nilai a sebesar 5\% $(0,05)$.

\section{Uji Validitas Instrumen Variabel Produk $\left(\mathbf{X}_{2}\right)$}

Hasil pengujian validitas instrumen variabel produk $\left(\mathrm{X}_{2}\right)$ dapat dilihat pada Tabel berikut ini :

Tabel 2. Hasil Uji Validitas Instrumen Variabel Produk ( $\left.\mathbf{X}_{2}\right)$

\begin{tabular}{|c|l|c|c|c|}
\hline No. & \multicolumn{1}{|c|}{ Pernyataan } & $\begin{array}{l}\text { Corrected } \\
\text { Item-Total } \\
\text { Correlation }\end{array}$ & $\mathbf{r}_{\text {tabel }}$ & Keterangan \\
\hline 1. & $\begin{array}{l}\text { Saya memilih produk } \\
\text { handphone pada CV. Digital } \\
\text { Store karena saya yakin produk } \\
\text { yang ditawarkan memiliki } \\
\text { kinerja yang baik. }\end{array}$ & 0,696 & 0,30 & Valid \\
\hline 2. & $\begin{array}{l}\text { Produk yang ditawarkan pada } \\
\text { CV. Digital Store memiliki fitur } \\
\text { yang optimal. }\end{array}$ & 0,665 & 0,30 & Valid \\
\hline 3. & $\begin{array}{l}\text { CV. Digital Store memiliki } \\
\text { produk yang mudah digunakan } \\
\text { untuk semua kalangan. }\end{array}$ & 0,697 & 0,30 & Valid \\
\hline 4. & $\begin{array}{l}\text { CV. Digital Store memiliki } \\
\text { kualitas produk yang memenuhi } \\
\text { spesifikasi yang dibutuhkan } \\
\text { konsumen. }\end{array}$ & 0,632 & 0,30 & Valid \\
\hline 5. & $\begin{array}{l}\text { Produk yang ditawarkan pada } \\
\text { CV. Digital Store memiliki } \\
\text { daya tahan yang kuat. }\end{array}$ & 0,898 & 0,30 & \\
\hline
\end{tabular}

Sumber : Hasil Penelitian, 2021 (Data Diolah)

Berdasarkan Tabel 2. di atas diperoleh bahwa hasil pengujian instrumen dari variabel produk memiliki nilai yang lebih besar dari 0,30. Dengan demikian, dapat 
disimpulkan bahwa seluruh instrumen pernyataan dari variabel produk yang digunakan adalah valid dan dapat digunakan dalam penelitian. Simpulan ini diperkuat dengan nilai signifikan (2-tailed) seluruh instrumen yang lebih kecil dari nilai $\alpha$ sebesar 5\% $(0,05)$.

\section{Uji Validitas Instrumen Variabel Lokasi $\left(\mathbf{X}_{3}\right)$}

Hasil pengujian validitas instrumen variabel lokasi $\left(\mathrm{X}_{3}\right)$ dapat dilihat pada Tabel berikut ini :

Tabel 3. Hasil Uji Validitas Instrumen Variabel Lokasi (X3)

\begin{tabular}{|c|c|c|c|c|}
\hline No. & Pernyataan & $\begin{array}{c}\text { Corrected Item- } \\
\text { Total } \\
\text { Correlation } \\
\end{array}$ & $\mathbf{r}_{\text {tabel }}$ & Keterangan \\
\hline 1. & $\begin{array}{l}\text { Lokasi CV. Digital Store di Jl. } \\
\text { Gatot Subroto No. } 30 \text { Plaza } \\
\text { Medan Fair lantai } 4 \text { banyak } \\
\text { dilalui alat transportasi umum. }\end{array}$ & 0,864 & 0,30 & Valid \\
\hline 2. & $\begin{array}{l}\text { Lokasi CV. Digital Store di Jl. } \\
\text { Gatot Subroto No. } 30 \text { Plaza } \\
\text { Medan Fair lantai } 4 \text { memiliki } \\
\text { tempat parkir yang luas dan } \\
\text { aman. }\end{array}$ & 0,740 & 0,30 & Valid \\
\hline 3. & $\begin{array}{l}\text { CV. Digital Store di Jl. Gatot } \\
\text { Subroto No. } 30 \text { Plaza Medan } \\
\text { Fair lantai } 4 \text { memiliki lokasi } \\
\text { usaha lingkungan yang } \\
\text { mendukung. }\end{array}$ & 0,806 & 0,30 & Valid \\
\hline 4. & $\begin{array}{l}\text { Lokasi CV. Digital Store di Jl. } \\
\text { Gatot Subroto No. } 30 \text { Plaza } \\
\text { Medan Fair lantai } 4 \text { merupakan } \\
\text { lokasi yang mudah ditemukan. }\end{array}$ & 0,695 & 0,30 & Valid \\
\hline
\end{tabular}

\section{Sumber : Hasil Penelitian, 2021 (Data Diolah)}

Berdasarkan Tabel 3. di atas diperoleh bahwa hasil pengujian instrumen dari variabel lokasi memiliki nilai yang lebih besar dari 0,30. Dengan demikian, dapat disimpulkan bahwa seluruh instrumen pernyataan dari variabel lokasi yang digunakan adalah valid dan dapat digunakan dalam penelitian. Simpulan ini diperkuat dengan nilai signifikan (2-tailed) seluruh instrumen yang lebih kecil dari nilai $\alpha$ sebesar 5\% $(0,05)$.

\section{Uji Validitas Instrumen Variabel Loyalitas Konsumen (Y)}

Hasil pengujian validitas instrumen variabel loyalitas konsumen (Y) dapat dilihat pada Tabel berikut ini :

Tabel 4. Hasil Uji Validitas Instrumen Variabel Loyalitas Konsumen (Y)

\begin{tabular}{|c|l|c|c|c|}
\hline No. & \multicolumn{1}{|c|}{ Pernyataan } & $\begin{array}{l}\text { Corrected } \\
\text { Item-Total } \\
\text { Correlation }\end{array}$ & $\mathbf{r}_{\text {tabel }}$ & Keterangan \\
\hline 1. & $\begin{array}{l}\text { Saya bersedia untuk datang } \\
\text { kembali melakukan transaksi } \\
\text { atau pembelian ulang produk } \\
\text { handphone pada CV. Digital } \\
\text { Store. }\end{array}$ & 0,815 & 0,30 & Valid \\
\hline 2. & $\begin{array}{l}\text { Saya akan merekomendasikan } \\
\text { produk handphone pada CV. }\end{array}$ & 0,911 & 0,30 & Valid \\
\hline
\end{tabular}




\begin{tabular}{|c|l|c|c|c|}
\hline & \multicolumn{2}{|l|}{ Digital Store kepada orang lain. } & & \\
\hline 3. & $\begin{array}{l}\text { Saya tidak akan memakai } \\
\text { produk handphone pada } \\
\text { perusahaan lain. }\end{array}$ & 0,763 & 0,30 & Valid \\
\hline 4. & $\begin{array}{l}\text { Saya terus membeli produk } \\
\text { handphone pada CV. Digital } \\
\text { Store walaupun harga produk } \\
\text { naik. }\end{array}$ & 0,759 & 0,30 & Valid \\
\hline
\end{tabular}

\section{Sumber : Hasil Penelitian, 2021 (Data Diolah)}

Berdasarkan Tabel 4. di atas diperoleh bahwa hasil pengujian instrumen dari variabel loyalitas konsumen memiliki nilai yang lebih besar dari 0,30. Dengan demikian, dapat disimpulkan bahwa seluruh instrumen pernyataan dari variabel loyalitas konsumen yang digunakan adalah valid dan dapat digunakan dalam penelitian. Simpulan ini diperkuat dengan nilai signifikan (2-tailed) seluruh instrumen yang lebih kecil dari nilai $\alpha$ sebesar $5 \%(0,05)$.

Hasil uji reliabilitas untuk desain produk, harga, produk lokasi dan loyalitas pelanggan seperti pada Tabel di bawah ini :

Tabel 5. Hasil Uji Reliabilitas Instrumen Variabel

\begin{tabular}{|c|l|c|c|c|}
\hline No. & \multicolumn{1}{|c|}{ Variabel } & Cronbach's Alpha & N of Items & Keterangan \\
\hline 1. & Harga $\left(\mathrm{X}_{1}\right)$ & 0,758 & 6 & Reliabel \\
\hline 2. & Produk $\left(\mathrm{X}_{2}\right)$ & 0,785 & 6 & Reliabel \\
\hline 3. & Lokasi $\left(\mathrm{X}_{3}\right)$ & 0,809 & 5 & Reliabel \\
\hline 4. & Loyalitas Konsumen $(\mathrm{Y})$ & 0,820 & 5 & Reliabel \\
\hline
\end{tabular}

Sumber : Hasil Penelitian, 2021 (Data Diolah)

Reliabilitas yang kurang dari 0,60 adalah kurang baik sedangkan 0,70 dapat diterima dan reliabilitas dengan Cronbach's Alpha 0,8 atau di atasnya adalah baik. Berdasarkan output yang diperoleh pada Tabel di atas diperoleh nilai koefisien reliabilitas pada variabel harga dan produk adalah dapat diterima sedangkan nilai koefisien reliabilitas pada variabel lokasi dan loyalitas konsumen adalah baik. Dengan demikian, variabel-variabel yang digunakan pada instrumen tersebut adalah reliabel dan dapat digunakan dalam penelitian.

\section{Pengujian Asumsi Klasik Uji Normalitas}

Untuk mendeteksi apakah residual berdistribusi normal atau tidak, ditunjukkan dengan analisis grafik histogram dan grafik Normal Probability Plotseperti Gambar di bawah ini : 


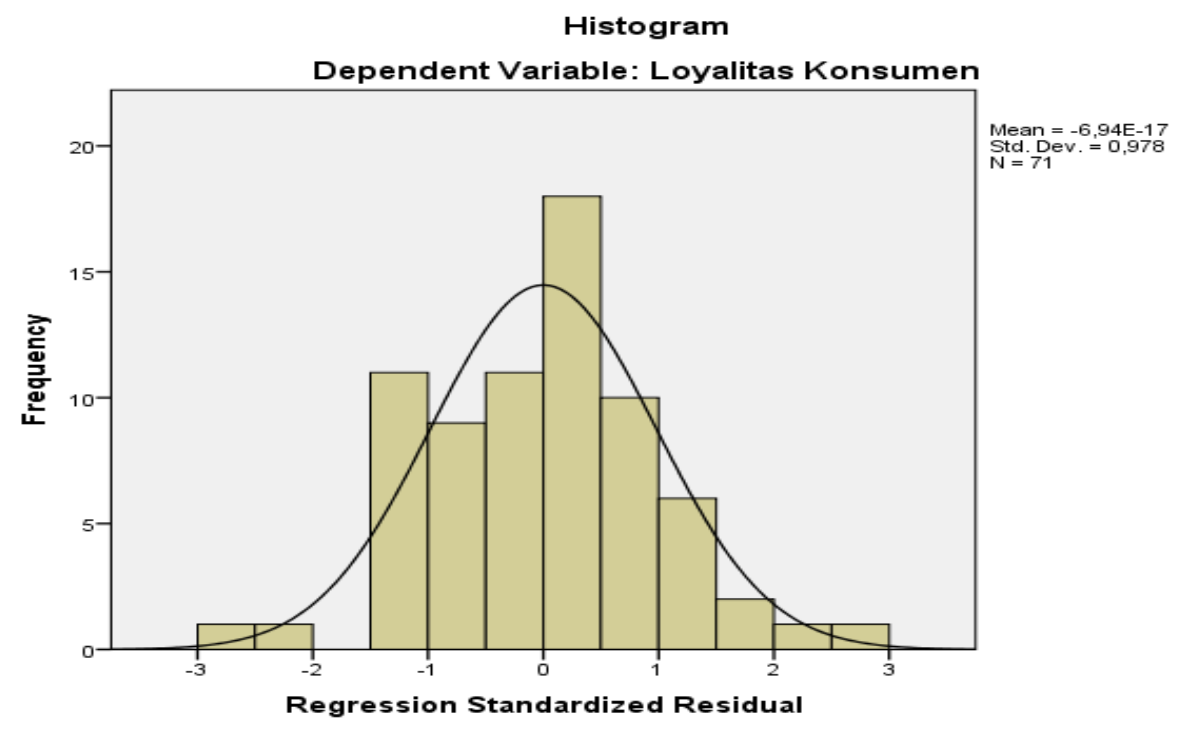

Sumber : Hasil Penelitian, 2021 (Data Diolah)

Gambar 1. Grafik Histogram Uji Normalitas Data

Dari Gambar 1. memperlihatkan bahwa variabel berdistribusi normal. Hal ini ditunjukkan oleh distribusi data tersebut di mana tidak melenceng ke kiri atau ke kanan.

Normal P-P Plot of Regression Standardized Residual

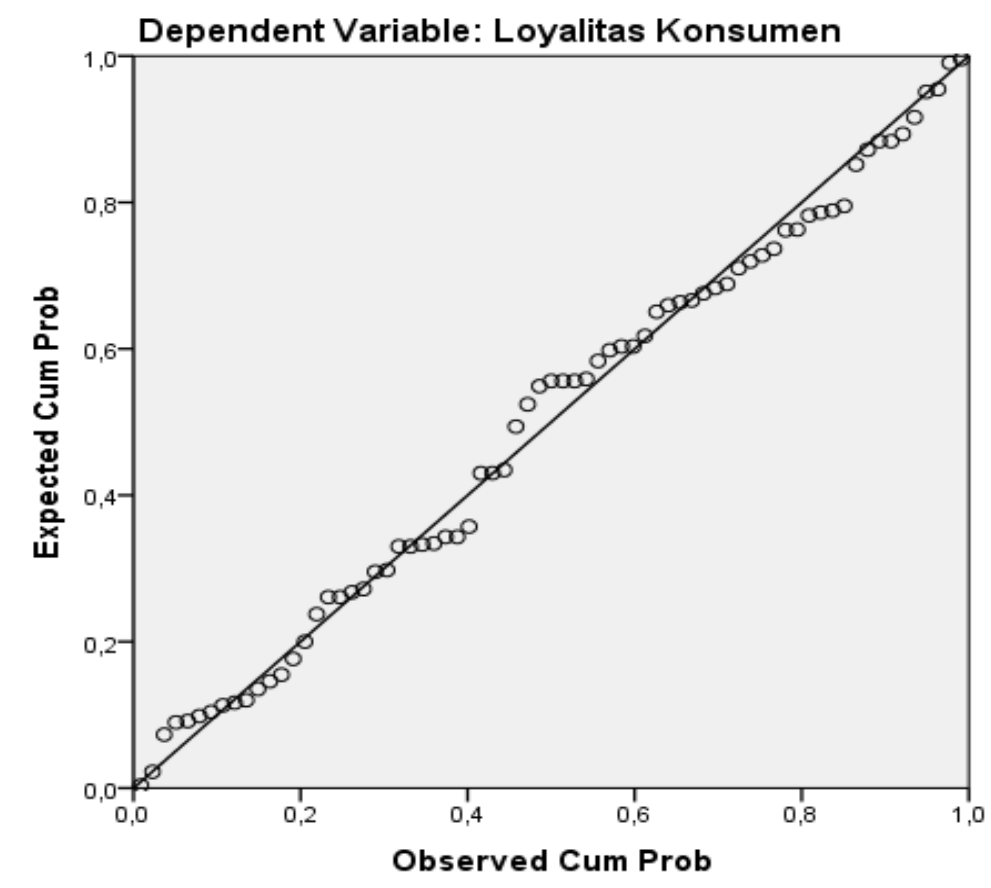

\section{Sumber : Hasil Penelitian, 2021 (Data Diolah)}

Gambar 2. Grafik P-Plot Normalitas

Dari Gambar 2. memperlihatkan bahwa penyebaran data berada pada sekitaran garis diagonal dan mengikuti garis arah diagonal maka nilai residual terstandarisasi. Dengan demikian, model regresi hipotesis tersebut memenuhi asumsi normalitas.

Menurut Priyatno (2016 : 38), "Uji normalitas dengan metodologi One-Sample Kolmogorov-Smirnov". Kriteria pengujiannya sebagai berikut :

1. Jika nilai signifikansi $>0,05$ maka data berdistribusi normal.

2. Jika nilai signifikansi $<0,05$ maka data tidak berdistribusi normal. 
Hasil uji One-Sample Kolmogorov-Smirnov seperti pada Tabel di bawah ini :

Tabel 6. Hasil Uji Kolmogorov-Smirnov

Hasil Uji Kolmogorov-Smirnov

One-Sample Kolmogorov-Smirnov Test

\begin{tabular}{|ll|r|}
\hline & & \multicolumn{2}{|c|}{$\begin{array}{c}\text { Unstandardized } \\
\text { Residual }\end{array}$} \\
\hline N & Mean & 71 \\
Normal Parameters & $0 \mathrm{E}-7$ \\
& Std. &, 82635422 \\
& Deviation &, 071 \\
Most Extreme Differences & Absolute &, 059 \\
& Positive &,- 071 \\
Kolmogorov-Smirnov Z & Negative &, 600 \\
Asymp. Sig. (2-tailed) & &, 864 \\
\hline
\end{tabular}

a. Test distribution is Normal.

b. Calculated from data.

Sumber : Hasil Penelitian, 2021 (Data Diolah)

Dari Tabel di atas dapat disimpulkan bahwa sig. K-S > 0,05 (nilai a) yaitu 0,864

$>0,05$. Dengan demikian, terima $\mathrm{H}_{0}$ artinya residual terdistribusi dengan normal.

\section{Uji Multikolinearitas}

Hasil uji multikolinearitas seperti pada Tabel di bawah ini :

Coefficients $^{\mathrm{a}}$

Tabel 7. Uji Multikolinearitas

\begin{tabular}{|rl|r|r|}
\hline \multicolumn{1}{|l|}{ Model } & \multicolumn{2}{|c|}{ Collinearity Statistics } \\
\cline { 3 - 5 } & (Constant) & \multicolumn{2}{|c|}{ VIF } \\
\hline \multirow{3}{*}{1} & Tolerance & \\
& Harga &, 161 & 6,216 \\
& Produk &, 204 & 4,901 \\
& Lokasi &, 268 & 3,730 \\
\hline
\end{tabular}

a. Dependent Variable: Loyalitas Konsumen

\section{Sumber : Hasil Penelitian, 2021 (Data Diolah)}

Dari Tabel 7. dapat dilihat bahwa nilai Tolerance $>0,1$ dan nilai VIF $<10$ maka tidak ditemukan masalah multikolinearitas dalam penelitian ini.

\section{Heterokedastisitas}

Hasil pengujian heterokedastisitas dengan grafik Scatterplot seperti pada Gambar di bawah ini : 


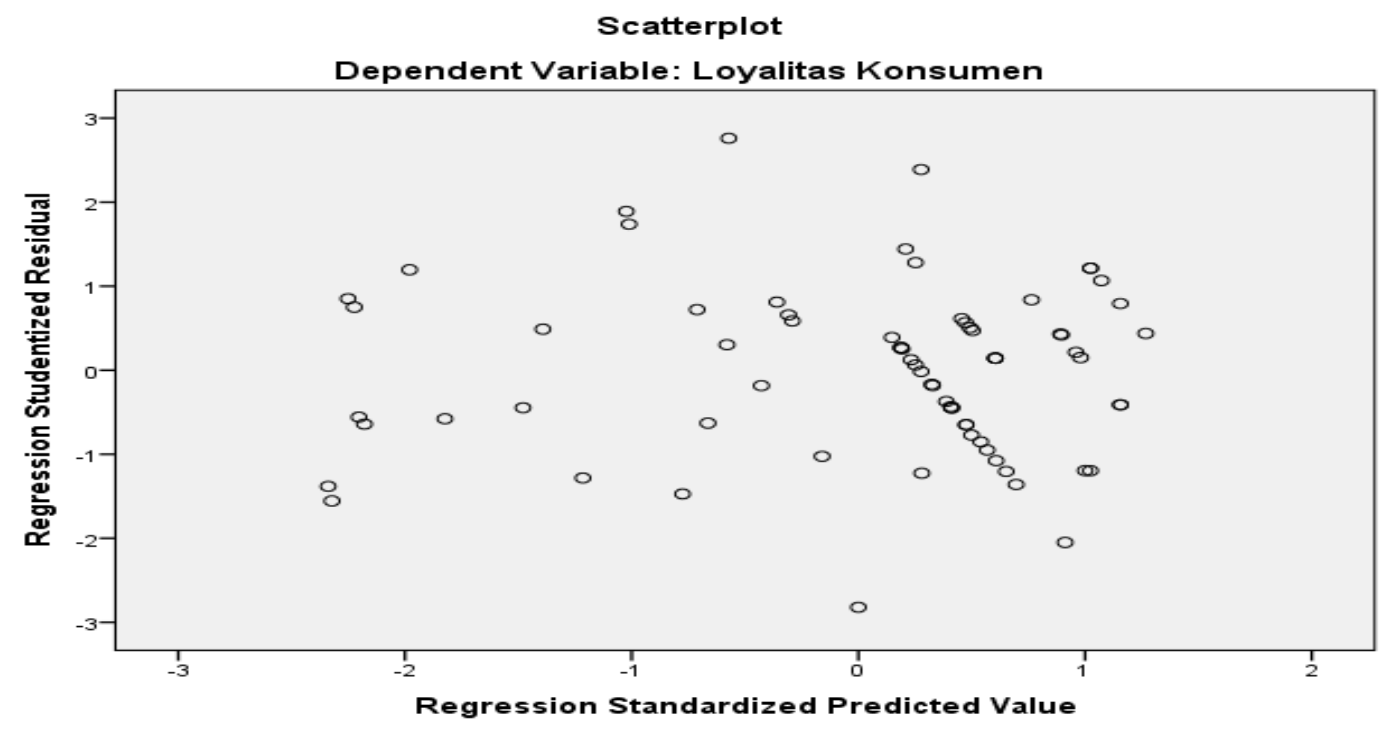

Sumber : Hasil Penelitian, 2021 (Data Diolah)

Gambar 3. Grafik Uji Heterokedastisitas

Dari Gambar 3. terlihat bahwa titik-titik menyebar di atas dan di bawah angka 0 pada sumbu Y. Dengan demikian, dapat disimpulkan persamaan regresi hipotesis ini terbebas dari asumsi heterokedastisitas.

\section{Pengujian Hipotesis}

\section{Hasil Uji Koefisien Regresi Linear Berganda}

Hasil analisis regresi linear berganda seperti pada Tabel di bawah ini :

Tabel 8. Analisis Regresi Linear Berganda

Coefficients ${ }^{\mathbf{a}}$
\begin{tabular}{|l|rr|r|r|}
\hline \multicolumn{1}{|l|}{ Model } & \multicolumn{2}{|c|}{ Unstandardized Coefficients } & $\begin{array}{c}\text { Standardized } \\
\text { Coefficients }\end{array}$ \\
\cline { 3 - 5 } & (Constant) & \multicolumn{2}{|c|}{ Std. Error } & \multicolumn{1}{c|}{ Beta } \\
\hline \multirow{4}{*}{1} & B &, 726 &, 582 &, 213 \\
& Harga &, 170 &, 072 &, 496 \\
& Produk &, 349 &, 057 &, 297 \\
\hline
\end{tabular}

a. Dependent Variable: Loyalitas Konsumen

\section{Sumber : Hasil Penelitian, 2021 (Data Diolah)}

Persamaan regresi linear berganda yang diperoleh yaitu :

$$
\mathrm{Y}=0,726+0,170 \mathrm{X}_{1}+0,349 \mathrm{X}_{2}+0,296 \mathrm{X}_{3}+\mathrm{e}
$$

Pada persamaan tersebut dapat dilihat bahwa nilai konstanta (a) $=0,726$. Artinya walaupun variabel bebas yaitu harga $\left(\mathrm{X}_{1}\right)$, produk $\left(\mathrm{X}_{2}\right)$ dan lokasi $\left(\mathrm{X}_{3}\right)$ bernilai tetap maka loyalitas konsumen (Y) pada CV. Triple Delapan Group Medan adalah tetap sebesar 0,726 .

Variabel harga $X_{1}\left(b_{1}\right)=0,170$. Hal ini menunjukkan bahwa variabel harga berpengaruh secara positif dan signifikan terhadap loyalitas konsumen atau dengan kata lain jika variabel harga semakin diperbaiki sebesar satu-satuan maka loyalitas konsumen akan bertambah sebesar 0,170 .

Variabel produk $\mathrm{X}_{2}\left(\mathrm{~b}_{2}\right)=0,349$. Hal ini menunjukkan bahwa variabel produk berpengaruh secara positif dan signifikan terhadap loyalitas konsumen atau dengan kata 
lain jika variabel produk semakin diperbaiki sebesar satu-satuan maka loyalitas konsumen akan bertambah sebesar 0,349.

Variabel lokasi $\mathrm{X}_{3}\left(\mathrm{~b}_{3}\right)=0,296$. Hal ini menunjukkan bahwa variabel lokasi berpengaruh secara positif dan signifikan terhadap loyalitas konsumen atau dengan kata lain jika variabel lokasi semakin diperbaiki sebesar satu-satuan maka loyalitas konsumen akan bertambah sebesar 0,296.

\section{Uji-t (Parsial)}

Hasil uji-t seperti pada Tabel di bawah ini :

\section{Coefficients $^{\mathbf{a}}$}

\section{Tabel 9. Hasil Uji Parsial}

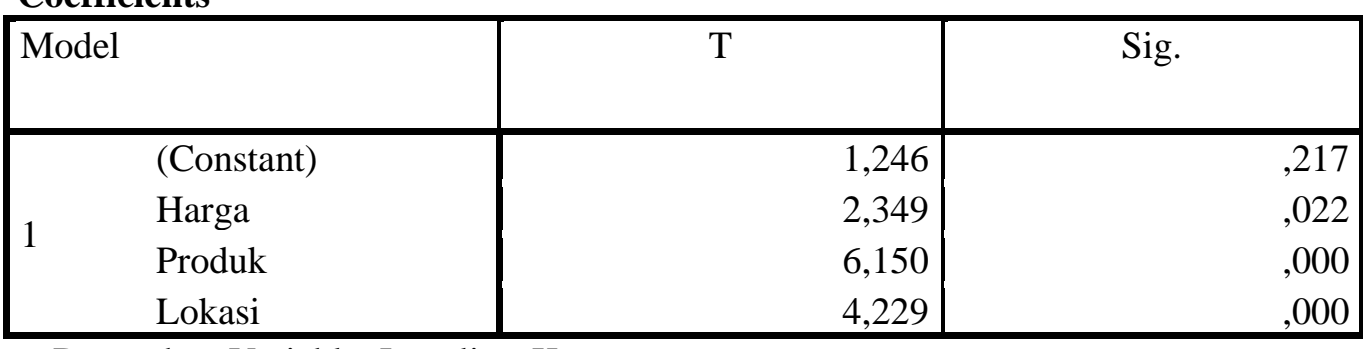

a. Dependent Variable: Loyalitas Konsumen

\section{Sumber : Hasil Penelitian, 2021 (Data Diolah)}

Nilai tabel diperoleh dengan cara :

Penyebut $(\mathrm{df})=\mathrm{n}-\mathrm{k}$

$$
\begin{aligned}
& =71-4 \\
& =67, t_{\text {tabel }} 0,05 .
\end{aligned}
$$

Jadi, tabel $(67)=1,6679$.

Berdasarkan Tabel 9. di atas diperoleh hasil sebagai berikut :

1. Nilai thitung untuk variabel harga $(2,349)$ lebih besar dibandingkan dengan nilai tabel $(1,6679)$ atau nilai sig. $t$ untuk variabel harga $(0,022)$ lebih kecil dari $\alpha$ atau alpha $(0,05)$. Berdasarkan hasil yang diperoleh maka menolak $\mathrm{H}_{0}$ dan menerima $\mathrm{H}_{1}$ untuk variabel harga. Dengan demikian, secara parsial harga berpengaruh positif dan signifikan terhadap loyalitas konsumen pada CV. Triple Delapan Group Medan.

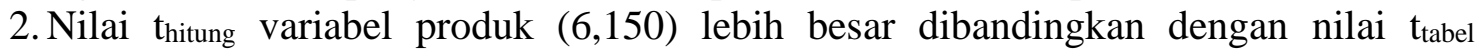
$(1,6679)$ atau nilai sig. $t$ untuk variabel produk $(0,000)$ lebih kecil dari $\alpha$ atau alpha $(0,05)$. Berdasarkan hasil yang diperoleh maka menolak $\mathrm{H}_{0}$ dan menerima $\mathrm{H}_{1}$ untuk variabel produk. Dengan demikian, secara parsial produk berpengaruh positif dan signifikan terhadap loyalitas konsumen pada CV. Triple Delapan Group Medan.

3. Nilai $t_{\text {hitung }}$ variabel lokasi $(4,229)$ lebih besar dibandingkan dengan nilai tabel $(1,6679)$ atau nilai sig. $\mathrm{t}$ untuk variabel lokasi $(0,000)$ lebih kecil dari $\alpha$ atau alpha $(0,05)$. Berdasarkan hasil yang diperoleh maka menolak $\mathrm{H}_{0}$ dan menerima $\mathrm{H}_{1}$ untuk variabel lokasi. Dengan demikian, secara parsial lokasi berpengaruh positif dan signifikan terhadap loyalitas konsumen pada CV. Triple Delapan Group Medan.

\section{Uji F (Serempak)}

Hasil uji F dapat dilihat pada Tabel di bawah ini :

Tabel 10. Hasil Uji Serempak ANOVA $^{\mathrm{a}}$

\begin{tabular}{|l|c|r|r|c|c|}
\hline Model & $\begin{array}{c}\text { Sum of } \\
\text { Squares }\end{array}$ & Df & Mean Square & F & Sig. \\
\hline $1 \quad$ Regression & 490,566 & 3 & 163,522 & 229,203 &, $000^{\mathrm{b}}$ \\
\hline
\end{tabular}




\begin{tabular}{|c|c|c|c|}
\hline $\begin{array}{l}\text { Residual } \\
\text { Total }\end{array}$ & $\begin{array}{r}47,800 \\
538,366\end{array}$ & $\begin{array}{l}67 \\
70\end{array}$ & 713 \\
\hline
\end{tabular}

a. Dependent Variable: Loyalitas Konsumen

b. Predictors: (Constant), Lokasi, Produk, Harga

Sumber : Hasil Penelitian, 2021 (Data Diolah)

Nilai $F_{\text {tabel }}$ diperoleh dengan cara :

Derajat pembilang $=\mathrm{k}-1=4-1=3$.

Derajat penyebut $=\mathrm{n}-\mathrm{k}=71-4=67$.

Nilai $\mathrm{F}_{\text {tabel }}(3 ; 67), \mathrm{F}_{\text {tabel }} 0,05$.

Jadi, $\mathrm{F}_{\text {tabel }}(3 ; 67)=2,74$.

Pada Tabel 10. di atas dapat diketahui bahwa nilai $F_{\text {hitung }}$ adalah 229,203. Pada tingkat kesalahan $\alpha=5 \%$ nilai $\mathrm{F}_{\text {hitung }}>$ dari nilai $\mathrm{F}_{\text {tabel }}$ tersebut signifikan dan nilai signifikan $0,000<0,05$ pada nilai $F_{\text {tabel }}=2,74$. Berdasarkan kriteria uji hipotesis jika $\mathrm{F}_{\text {hitung }}>\mathrm{F}_{\text {tabel }}$ maka $\mathrm{H}_{0}$ ditolak dan $\mathrm{H}_{1}$ diterima artinya variabel harga $\left(\mathrm{X}_{1}\right)$, produk $\left(\mathrm{X}_{2}\right)$ dan lokasi $\left(\mathrm{X}_{3}\right)$ secara serempak berpengaruh positif dan signifikan terhadap loyalitas konsumen (Y) pada CV. Triple Delapan Group Medan.

\section{Uji Koefisien Determinasi $\left(\mathbf{R}^{2}\right)$}

Hasil uji koefisien determinasi seperti pada Tabel di bawah ini :

Tabel 11. Pengujian Koefisien Determinasi

Model Summary $\mathbf{b}^{\mathbf{b}}$
\begin{tabular}{|l|r|r|r|r|}
\hline Model & $\mathrm{R}$ & R Square & $\begin{array}{c}\text { Adjusted R } \\
\text { Square }\end{array}$ & \multicolumn{2}{|c|}{ Std. Error of the Estimate } \\
\hline 1 &, $955^{\mathrm{a}}$ &, 911 &, 907 &, 845 \\
\hline
\end{tabular}

a. Predictors: (Constant), Lokasi, Produk, Harga

b. Dependent Variable: Loyalitas Konsumen

\section{Sumber : Hasil Penelitian, 2021 (Data Diolah)}

Berdasarkan Tabel 11. di atas diperoleh nilai koefisien determinasi ysng disesuaikan sebesar 0,907. Hal ini menunjukkan bahwa 90,7\% variabel harga, produk dan lokasi $\left(\mathrm{X}_{1}, \mathrm{X}_{2}\right.$ dan $\left.\mathrm{X}_{3}\right)$ mampu menjelaskan variabel loyalitas konsumen $(\mathrm{Y})$ pada CV. Triple Delapan Group Medan sedangkan sisanya 9,3\% merupakan pengaruh dari variabel bebas lain yang tidak dijelaskan oleh model penelitian seperti variabel promosi, kualitas pelayanan dan minat beli konsumen.

\section{Pembahasan} berikut :

Berdasarkan hasil pengujian parsial dan serempak dapat dijelaskan sebagai

Berdasarkan hasil uji hipotesis di atas dapat disimpulkan bahwa uji parsial (uji-t) pada variabel harga berpengaruh positif dan signifikan terhadap loyalitas konsumen. Hal ini terlihat dari nilai signifikansi $0,022<0,05$ dan nilai $t_{\text {hitung }}(2,349)>t_{\text {tabel }}(1,6679)$ artinya jika variabel harga lebih ditingkatkan maka loyalitas konsumen juga akan meningkat. Penelitian ini sesuai dengan hasil dari penelitian terdahulu atas nama Adit Wahyu Wicaksono (2017) yang menyatakan bahwa terdapat pengaruh secara positif dan signifikan harga terhadap loyalitas konsumen.

Berdasarkan hasil uji hipotesis di atas dapat disimpulkan bahwa uji parsial (uji-t) pada variabel produk berpengaruh positif dan signifikan terhadap variabel loyalitas konsumen. Hal ini terlihat dari nilai signifikansi $0,000<0,05$ dan nilai thitung $(6,150)>$ $\mathrm{t}_{\text {tabel }}(1,6679)$ artinya jika variabel produk lebih ditingkatkan maka loyalitas konsumen 
juga akan meningkat. Penelitian ini sesuai dengan hasil dari penelitian terdahulu atas nama Maria Novalina Butar-butar (2018) yang menyatakan bahwa terdapat pengaruh secara positif dan signifikan produk terhadap loyalitas konsumen.

Berdasarkan hasil uji hipotesis di atas dapat disimpulkan bahwa uji parsial (uji-t) pada variabel lokasi berpengaruh positif dan signifikan terhadap loyalitas konsumen. Hal ini terlihat dari nilai signifikansi $0,000<0,05$ dan nilai thitung $(4,229)>t_{\text {tabel }}(1,6679)$ artinya jika variabel lokasi lebih ditingkatkan maka loyalitas konsumen juga akan meningkat. Penelitian ini sesuai dengan hasil dari penelitian terdahulu atas nama Kuncoro (2017) yang menyatakan bahwa terdapat pengaruh secara positif dan signifikan lokasi terhadap loyalitas konsumen.

Pada uji serempak (uji F) variabel harga, produk dan lokasi secara serempak berpengaruh positif dan signifikan terhadap variabel loyalitas konsumen pada CV. Triple Delapan Group Medan serta pengaruhnya adalah positif dengan taraf signifikan $(\alpha)$ adalah 5\%. Dengan melihat probabilitasnya (sig.) yang lebih kecil dari taraf signifikan $(0,000<0,05)$ dan nilai $F_{\text {hitung }}(229,203)>F_{\text {tabel }}(2,74)$ maka dapat disimpulkan bahwa model persamaan tersebut diterima dan berpengaruh positif. Penelitian ini sesuai dengan hasil dari penelitian terdahulu atas nama Desi Purwanti Atmaja (2018) yang menyatakan bahwa terdapat pengaruh secara positif dan signifikan harga, produk dan lokasi terhadap loyalitas pelanggan.

Dari hasil penelitian ini peneliti memperoleh nilai koefisien determinasi yang disesuaikan sebesar 0,907. Hal ini menunjukkan bahwa 90,7\% variabel harga, produk dan lokasi $\left(\mathrm{X}_{1}, \mathrm{X}_{2}\right.$ dan $\left.\mathrm{X}_{3}\right)$ mampu menjelaskan variabel loyalitas konsumen (Y) pada CV. Triple Delapan Group Medan sedangkan sisanya 9,3\% merupakan pengaruh dari variabel bebas lain yang tidak dijelaskan oleh model penelitian seperti variabel promosi, kualitas pelayanan dan minat beli konsumen.

\section{PENUTUP}

\section{Simpulan} berikut :

Berdasarkan hasil penelitian maka peneliti memberikan simpulan sebagai

1. Secara parsial harga berpengaruh positif dan signifikan terhadap loyalitas konsumen pada CV. Triple Delapan Group Medan.

2. Secara parsial produk berpengaruh positif dan signifikan terhadap loyalitas konsumen pada CV. Triple Delapan Group Medan.

3. Secara parsial lokasi berpengaruh positif dan signifikan terhadap loyalitas konsumen pada CV. Triple Delapan Group Medan.

4. Secara serempak harga, produk dan lokasi berpengaruh positif dan signifikan terhadap loyalitas konsumen pada CV. Triple Delapan Group Medan.

5. Berdasarkan hasil uji koefisien determinasi yang disesuaikan (adjusted $\mathrm{R}$ square) sebesar 0,907. Hasil ini menunjukkan bahwa 90,7\% variabel harga $\left(\mathrm{X}_{1}\right)$, produk $\left(\mathrm{X}_{2}\right)$ dan lokasi $\left(\mathrm{X}_{3}\right)$ mampu menjelaskan variabel loyalitas konsumen (Y) padaCV. Triple Delapan Group Medan sedangkan sisanya 9,3\% merupakan pengaruh variabel bebas lain yang tidak dijelaskan seperti variabel promosi, kualitas pelayanan dan minat beli konsumen.

\section{Saran}

Berdasarkan hasil penelitian maka peneliti menyarankan sebagai berikut : 
1. Sebaiknya perusahaan mempertimbangkan faktor harga seperti perusahaan menawarkan harga produk yang memiliki manfaat yang lebih dari pada perusahaan yang lain, harga produk yang ditawarkan bervariasi sehingga dijangkau oleh konsumen dan perusahaan memberikan potongan harga kepada konsumen yang loyal.

2. Sebaiknya perusahaan mempertimbangkan faktor produk yang diproduksi perusahaan seperti memproduksi produk yang berkinerja baik, memiliki produk yang mudah digunakan untuk semua kalangan dan memiliki kualitas produk yang memenuhi spesifikasi yang dibutuhkan konsumen.

3. Sebaiknya perusahaan mempertimbangkan faktor lokasi yang strategis seperti perusahaan banyak dilalui alat transportasi umum, perusahaan memiliki tempat parkir yang luas dan aman serta memiliki lokasi usaha lingkungan yang mendukung.

4. Sebaiknya perusahaan mempertimbangkan faktor loyalitas konsumen seperti menawarkan harga sesuai dengan kualitas produk yang diterima konsumen, menyediakan barangsesuai dengan trend masa kini dan memproduksi produk yang bervariasi desainnya.

5. Untuk mempertahankan harga yang terjangkau, sebaiknya perusahaan mempertimbangkan dari segi respon terhadap kenaikan harga, penilaian mengenai harga secara keseluruhan dan memilih metodologi penetapan harga. Untuk mempertahankan produk yang beragam, sebaiknya perusahaan mempertimbangkan dari segi daya tahan, fitur dan kesesuaian dengan spesifikasi yang dibutuhkan konsumen. Untuk mempertahankan lokasi yang mudah diakses oleh konsumen, sebaiknya perusahaan mempertimbangkan dari segi visibilitas, aksesbilitas dan memiliki fasilitas yang memadai. Untuk mempertahankan loyalitas konsumen, sebaiknya perusahaan mempertimbangkan faktor lain seperti promosi, kualitas pelayanan dan minat beli konsumen.

\section{DAFTAR RUJUKAN}

Amirullah. 2016. Pengantar Manajemen. Yogyakarta : Mitra Wacana Media Indonesia. Arikunto, Suharsimi. 2017. Prosedur Penelitian. Jakarta : PT. Bina Aksara.

Atmaja, Desi Purwanti. 2018. Pengaruh Produk, Harga, Lokasi dan Kualitas Pelayanan terhadap Keputusan Pembelian pada Kopitiam Oey Surabaya. Artikel Jurnal. STIE PETRA.

Butar-butar, Maria Novalina. 2018. Pengaruh Harga, Iklan, Produk dan Positioning terhadap Keputusan Pembelian Handphone (Studi Kasus pada Pembeli Handphone Merek Oppo). Artikel Skripsi. USU.

Ferdinand, Augusty. 2017. Metodologi Riset untuk Bisnis dan Ekonomi. Jakarta : Erlangga.

Ghozali, H. Imam. 2018. Metodologi Penelitian Kuantitatif, Kualitatif dan $R \& D$. Bandung : PT. Alfabeta.

Griffin, Jill. 2018. Customer Loyalty. Jakarta : Erlangga.

Hasan, Ali. 2018. Marketing. Cetakan Pertama. Yogyakarta : Media Pressdindo.

Kartajaya, Hermawan. 2016. Marketing in Venus. Jakarta : Gramedia Pustaka Utama.

Kotler, Philip. 2017. Manajemen Pemasaran. Jilid I. Edisi Keduabelas. Jakarta : Erlangga.

. 2019. Manajemen Pemasaran. Jilid II. Edisi Keduabelas. Jakarta : Erlangga. 
Kotler, Philip dan Armstrong, Gary. 2018. Prinsip-prinsip Pemasaran. Cetakan Ketiga. Edisi Keduabelas. Jakarta : Erlangga.

Kuncoro. 2017. Pengaruh Harga, Lokasi dan Kualitas Pelayanan terhadap Keputusan Pembelian pada Toko Ponsel Mega Seluler Surakarta. Artikel Jurnal Administrasi Bisnis. UNSRAT.

Laksana, Fajar. 2019. Manajemen Pemasaran Jasa. Edisi I. Yogyakarta : Graha Ilmu. . 2019. Manajemen Pemasaran. Yogyakarta : Graha Ilmu.

Lupiyoadi, Rambat. 2016. Manajemen Pemasaran Jasa. Edisi 3. Jakarta : Salemba Empat.

Manullang, M.. 2019. Dasar-dasar Manajemen. Yogyakarta : Bulaksumur.

Maylina, Wenny. 2016. Konsep dan Implikasi untuk Strategi dan Penelitian Pemasaran. Jakarta : Prenada Media.

Oliver, Ricard, L.. 2019. Satisfaction a Behavioral Perspective on the Consumer. Jakarta : Salemba Empat.

Rangkuti, Freddy. 2018. Manajemen Pemasaran di Indonesia Analisis, Perencanaan, Implementasi dan Pengendalian. Edisi Pertama. Jilid I. Jakarta : Salemba Empat.

Sarwono, Jonathan. 2016. Metodologi Penelitian untuk Skripsi dan Tesis Bisnis. Jakarta : Rajawali Press.

Sarwono, Jonathan dan Suhayati. 2016. Aplikasi Analisis Multivariat dengan Program SPSS. Edisi Ketiga. Cetakan Pertama. Yogyakarta : Graha Ilmu.

Setyaningrum, Ari. 2017. Manajemen Pemasaran dan Pemasaran Jasa. Depok : PT Raja Grafindo Persada.

Stanton, William J.. 2017. Manajemen Pemasaran, Analis Perencanaan dan Pengendalian. Jilid II. Edisi Millenium. Cetakan Kedua. Jakarta : Erlangga.

Sugiyono. 2016. Metodologi Penelitian. Jakarta : PT. Salemba Empat.

Suwarman, Ujang. 2019. Prilaku Konsumen. Jakarta : Ghalia Indonesia.

Swasta, Bayu D. H.. 2019. Pengantar Bisnis Modern, Pengantar Ekonomi Perusahaan Modern. Jakarta : Liberty.

Tjiptono, Fandy. 2017. Strategi Pemasaran. Edisi III. Yogyakarta : Andi.

Utami, Christina Whidya. 2016. Manajemen Ritel : Strategi dan Implementasi Ritel Modern. Jakarta : Salemba Empat.

Wibowo. 2016. Statistika untuk Penelitian. Bandung : PT. Alfabeta.

Wicaksono, Adit Wahyu. 2017. Pengaruh Kualitas Produk, Harga dan Promosi terhadap Keputusan Pembelian pada Erafone Mega-Store Solo. Artikel Jurnal Ekonomi Manajemen. UBHARA. 